\title{
Relationship Marketing In Niger Delta's Oil Communities
}

\author{
Kola Sonaike, Ph.D., American InterContinental University, Houston, Texas, USA
}

\begin{abstract}
This qualitative phenomenological case study is based on the exploration and production activities of a major oil company in Nigeria, the company's experiences within its operating community, and the relationship marketing actions that the company may take in order to maintain general non-disruptive operational atmosphere in the area. Data was collected by interviewing 25 of the stakeholders within the community (Creswell, 2007) to determine their opinions on the general tension in the area as related to the community's relationship with the major oil company. The interviewees were then asked for their opinions on possible steps that can be taken toward resolution of the problem of unrests in the area resulting from the operations of the major oil company. Specifically, in-depth semi-structured interview methodology was used (Moustakas, 1994). Each participant was asked the following three questions: What do you feel, in general, about your experience of the different unrests that have occurred between the particular major oil company and the host community in the recent past? What do you think can be done to resolve the problems that periodically lead to these unrests? Who is best suited to implement permanent solution to the problem(s)? The data collected was analyzed for "themes," that is, clusters of meanings from the significant statement, sentences, or quotes, obtained from the interview transcriptions (Creswell, 2007). The researcher's repeated "lived" experiences (Moustakas, 1994) of the problem of unrest in the area, was also relevant. Results showed that community leaders and some of the other stakeholders in the community desire a greater development of the relationship between the company and the community. They feel greater involvement of the community in the major oil company's projects undertaken for the community would help. Employment of more citizens of the community in technical areas such as engineering and geology are also desirable. In this connection, the company may consider some form of community tutoring or educational upgrade programs to bring high school students in the community up to speed in mathematics and other science subjects. Further, even though the research showed that the major oil company annually budgets substantial amount and carries out infrastructural projects for the community, the general feeling is that an increase in the level and scope would be advantageous for the company's long-term operations in the community.
\end{abstract}

Keywords: Oil; Community; Marketing; Relationship; Operations; Phenomenological; Projects; Infrastructure

\section{INTRODUCTION}

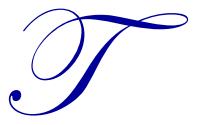

he struggle against transnational oil corporations in the Niger delta intensified in the 1990s after the Movement for the Survival of the Ogoni People (MOSOP) was formed to protest the exploitation of petroleum resources in Ogoni territory (Synge, 2006). In 1998, the Ijaw Youth Congress (IYC) issued the Kaiama declaration, which essentially mobilized youths throughout Ijaw communities against the transnational oil corporations and the Nigerian government (Tuodolo and Ogoriba, 2002). Protests against the federal government and oil companies in the Niger delta region have since developed into a militant struggle for resource control and the right to self-determination (Ikelegbe, 2006; Olusakin, 2006; Onuoha, 2006; Watts, 2004). The escalation of violence, which included the terrorist acts of kidnapping, bombing of oil installations, killings, property damage, and many other acts by different ethnic groups in the Niger delta, has continued to reduce Nigeria's oil output in the world market (Cohen, 2008). Although Nigerians have witnessed numerous social, religious, economic, and political unrests, military coups, students and labor riots that continue to escalate by the day, none of these riots is close to what is experienced almost daily in the Niger delta (Ighodaro, 2005). According 
to Okonta and Douglas (2001) and Oyefusi (2007), Niger delta residents have always been dominated and controlled by national leaders and leaders of outside corporations dealing in natural resources. The region has therefore been the center of several conflicts between the indigenous residents and the oil companies, the Nigerian state, the law enforcement officials, and between the different ethnic groups in the region (Ogonor, 2003; Oyefusi, 2007). These conflicts have resulted mainly from different complaints of environmental degradation in the region, general underdevelopment, and unfair distribution of oil revenue (Ogonor, 2003; Onwuka, 2005).

Since it began exploration and production activities in Nigeria in the late 1950s/early 1960s, the exploration and production oil company operating within the community in which this study was conducted enjoyed relative peace until the late 1990s and the turn of the century when problems of different kinds arose from the immediate community of the company. Since about 1999, the company has faced fierce opposition and different operational barriers from its immediate community that has continued to disturb its production and has continued to lead to losses of several million dollars of revenue virtually on an annual basis. According to Payne, Christopher, Clark, \& Peck (1995), relationship marketing has been practiced for many years by leading industrial companies and it is in industrial markets that the subject has its origin. In the case of this major oil company, the land on which their entire onshore facilities are built were acquired, on lease basis, from the community. A sort of owner-customer relationship therefore exists between the two parties. The onshore facilities are critical to the operation of the company: all offshore production first has to be piped onshore for treatment, storage, and measurement, prior to being piped offshore for shipment to the United States (U.S.) through very large crude carriers (VLCC). The tension between the company and the host community is so fierce, so unending, and so disruptive that from time to time, questions are asked as to what can be done to bring lasting peace to the area and to turn the untoward situation around. The problem is largely due to perennial government neglect of the community. Since, however, the federal government of Nigeria is in joint venture partnership with the major oil company, the community sees the company as the government they know and forcefully make unending demands on the company. From time to time, facilities have been shut, roads have been blocked, aircrafts have been grounded, workers have been assaulted, and company workers living within the community have been attacked and forced to run for their lives. The efforts of the company in the areas of provisions of scholarships, renovation of schools and hospitals, construction of roads, provision of potable water, provision of undisrupted electricity, and special treatments meted out to suppliers and contractors from within the community seeking work from the company, seem not to be paying off, as expected. There is truly a relationship marketing problem that needs full study and adequate recommendations for lasting solution. This is increasingly the case as the company has come to stay for a very long time; the company's petroleum and natural gas reserves in the area is increasing daily with new discoveries coming on the scene and with new facilities being installed and new engineering, procurement, construction and installation (EPCI) contracts being awarded on a continuous basis, by the company.

\section{LITERATURE REVIEW}

Many scholars have researched the growing concept of relationship marketing in many ares of the business world. Berry and Gresham (1986), for example, examined this concept from the point of view of the retailing industry. They posit that relationship retailing means the attraction, retention, and enhancement of client relationships. According to them, good service is necessary to retain the relationship while good selling is necessary to enhance it. Relationships have to be customized to meet each client's needs and preferences. These preferences are learned and the information is captured and stored so that it can be readily accessed and used to the best advantage in merchandising and serving client's requirements. Berry \& Gresham (1986) assert that companies that put in these extra efforts are able to translate customers to clients. Although such retailers offering personal service may look like other businesses, they do not feel the same way to their customers. According to Beaton and Beaton (1995), although service value continues to be a pivotal concept in contemporary services marketing and management, the arrival of relationship marketing on the scene is surely leading to a paradigm shift in the study and practice of marketing. They submit that relationship marketing is concerned with the identification of a reliable predictor of stable long-term relationships between buyers and sellers. Further, commitment, which can be conceptualized so as to incorporate service value as one of its determining variables, is set to become the principal concern of managers in service organizations. Beaton and Beaton (1995) submit that client relationships are increasingly becoming a conscious part of competitive strategy. This is due to factors such as time-based competition, total quality management (TQM), just-in-time (JIT) management, early supplier involvement, cost 
pressures, globalization of markets and international marketing, increased technical co-operation, downsizing of business, changes in production and operating structures, and the need for greater organizational flexibility (Wilson and Mummalaneni, 1988). Commitment has come to represent the continued stability of a relationship at the conceptual level, and its manifestations serve as surrogate measures of the likely longevity of the marriage between buyer and seller, service provider and client.

Reichheld (1993) posits that many managers mistakenly believe that the sole mission of the company is to provide value to investors. This is not so, as the true mission of the organization is to create value for the triad of customers, employees, and investors. He asserts that in the long term, corporate success will depend on serving these three segments adequately. Otherwise, no one in the relationship, including shareholders, will profit in the long run. According to Reichheld (1993), loyalty-based management, which focuses on customer and employee retention to enhance profitability, goes beyond the typical customer satisfaction surveys. Rather, the success of such a strategy is based on the realization that satisfied customers are not necessarily loyal. In a loyalty-based strategy, the goal of marketing is to manage toward "zero defection," which then can be measured in terms of cash flow due to the link between loyalty, value, and profit. It should be realized that all cash flow originates from the customer's wallet. Each member of the trilogy contributes some combination of time, money, energy, and expertise: and to succeed, a business must contribute even more value in return. Returns will be maximized by creating and allocating value in such a manner as to minimize churn in the business system because the learning and trust required to sustain value creation cannot exist in an unstable high-churn system.

In their contribution to the subject of relationship marketing, Bowen and Lawler (1992) looked particularly at the empowerment of service workers. They assert that managers need to make sure that there is a good fit between their organizational needs and their approach to frontline employees. According to them, empowerment involves sharing with frontline employees information about the organization's performance, rewards based on the organization's performance, knowledge that enables employees to understand and contribute to organizational performance, and power to make decisions that influence organizational direction and performance. Bowen and Lawler (1992) gave the example of Federal Express, which in 1990 became the first service organization to win the Malcolm Baldrige National Quality Award. The company's motto is "people, service, and profits." They assert that behind its blue, white, and red planes and uniforms are self-managing work teams, gain-sharing plans, and empowered employees seemingly consumed with providing flexible and creative service to customers with varying needs. In summary, Bowen and Lawler (19920 submit that empowered employees bring the following gains to the organization: Quicker on-line responses to customer needs during service delivery; Quicker on-line responses to dissatisfied customers during service recovery; Employees feel better about their jobs and themselves; Employees will interact with customers with more warmth and enthusiasm; Empowered employees are great source of service ideas; and Great word-of-mouth advertising and customer retention.

Defining relationship marketing as the establishment, development, and maintenance of successful relational exchanges, Morgan and Hunt (1994) assert that the concept constitutes a major shift in marketing theory and practice. They theorized that successful relationship marketing requires relationship commitment and trust. According to them, commitment and trust are key because they encourage marketers to (1) work at preserving relationship investments by cooperating with exchange partners, (2) resist attractive short-term alternatives in favor of the expected long-term benefits of staying with existing partners, and (3) view potentially high-risk actions as being prudent because of the belief that their partners will not act opportunistically. Therefore, when both commitment and trust are present, they produce outcomes that promote efficiency, productivity, and effectiveness. In short, commitment and trust lead directly to cooperative behaviors that are conducive to relationship marketing success. Pels, Coviello, and Brodie (2001) argued that the environment, the buyer and seller's perception or interpretation of their environment, and their perception of their counterpart's offer/need structure will influence the exchange situation. They further submit that both the transactional and exchange paradigm (and their relevant approaches to marketing practice) will be appropriate. They state that the actor's perceptions and therefore influences on the exchange situation are not necessarily constant over time. According to Schlesinger (1983), the linkages between job satisfaction, service capability, and customer satisfaction variables yields several interesting results basically supporting the notion of employees' greater output with increased management support. When management rewards adequately, empowers effectively, and embraces better employees quality of work life, there is greater service capability, higher job satisfaction, and increased customer satisfaction and retention. 


\section{METHOD}

The research was qualitative and was a phenomenological case study carried out within the operating community of a particular major oil company in Nigeria. A combination of judgmental and convenience sampling was used (Baridam, 2001). The sampling was judgmental based on the researcher's personal experience in the area that spanned a period of 29 years. It was convenience sampling because of the accessibility of the researcher to the area being a long-term participant, on a professional level, in the Niger Delta's oil exploration and production activities. 25 participants from the community who had lived the experience of community violence were interviewed. 13 of the participants were males while 12 were females. 10 of the participants were aged above 30 years while 15 were aged between 18 and 30 years. 6 of the participants were traditional chiefs in the community while 4 were youth leaders. The interviews were semi-structured and consisted mainly of the following questions:

1. What do you feel, in general, about your experience of the different unrests that have occurred between the major oil company and the host community in the recent past?

2. What do you think can be done to resolve the problems that periodically lead to these unrests?

3. Who is best suited to implement permanent solution to the problem(s)?

According to Cooper and Schindler (2008), confidentiality implies a privacy guarantee to retain validity of the research, as well as to protect participants. For the purpose of this study, participants were assured that their responses will be anonymous and confidential. In this case, "confidential" implied that the primary investigator will be the only one who knows who answered what, while "anonymous" implied that the respondents' identities are not known by anyone. For this phenomenological case study, the researcher protected participants' confidentiality by reading out a nondisclosure statement to each participant prior to the beginning of the interview, by restricting access to participant's identification, by restricting access to data instruments where participants are identified in any form, and by not disclosing data subsets (Cooper and Schindler, 2008, p. 40). Similarly, participants' right to privacy were ensured by informing participants of their right to refuse to answer any questions or participate in the study, by obtaining verbal permission to interview participants, by limiting the time required for participation, and by scheduling field or phone interviews, appropriately (Cooper and Schindler, 2008, p. 40.) Even though notes were taken during the course of the interviews, the interviews were also tape-recorded following the consent of each participant. This greatly helped the richness of the data collected after transcription of the interviews. The data were then described appropriately, to ensure clarity.

Following description of the data, the researcher analyzed the data for specific themes, aggregating information into large clusters of ideas and providing details that support the themes. This analysis is "the development of issues," (Stakes, 1995, p. 123). This step removed overlapping and repetitive statements (Moustakas, 1994). Pattern matching was also used for data analysis. According to Creswell (2007), "patterns" is an aspect of data analysis in case study research where the researcher establishes patterns and looks for a correspondence between two or more categories to establish a small number of categories. Creswell (2007) recommends the Moustakas (1994) modification of phenomenological data that includes the researcher bringing personal experiences into the study, the recording of significant statements and meanings, and the development of descriptions to arrive at the essences of the experiences. This was the approach adopted in the data analysis. Having worked in this particular Niger Delta oil producing community for about 29 years and having "lived" the experience of community unrests and complaints a number of times, the researcher's experience aided the interpretation of the data collected.

The main focus was the identification of issues, which, in the opinion of the research participants, contributed to the unrests and complaints that had been experienced between the community and the major oil company, over the years. These issues and the opinions of the participants on who should be held responsible for them, and who is in the best position to resolve them, were further analyzed to identify the extent to which they result from the relationship between the major oil company and the community. The situation between the major oil company and their immediate community was viewed from a relationship marketing perspective. As posited by Morgan and Hunt (1994), relationship marketing has to do with the establishment, development, and maintenance of successful relational exchanges. This, according to the scholars, requires relationship commitment and trust. The data gathered from this qualitative phenomenological case study were therefore analyzed for specific themes, ideas, 
comments, and other information that identified gaps in this all-important area. We set out to identify, for example, where the major oil company's communication or lack of it, inclusion or lack of it, and any such factors, contributed to the recurrent crisis in the community. We also set out to identify comments related to trusts and lack of trusts between the major oil company and their host community.

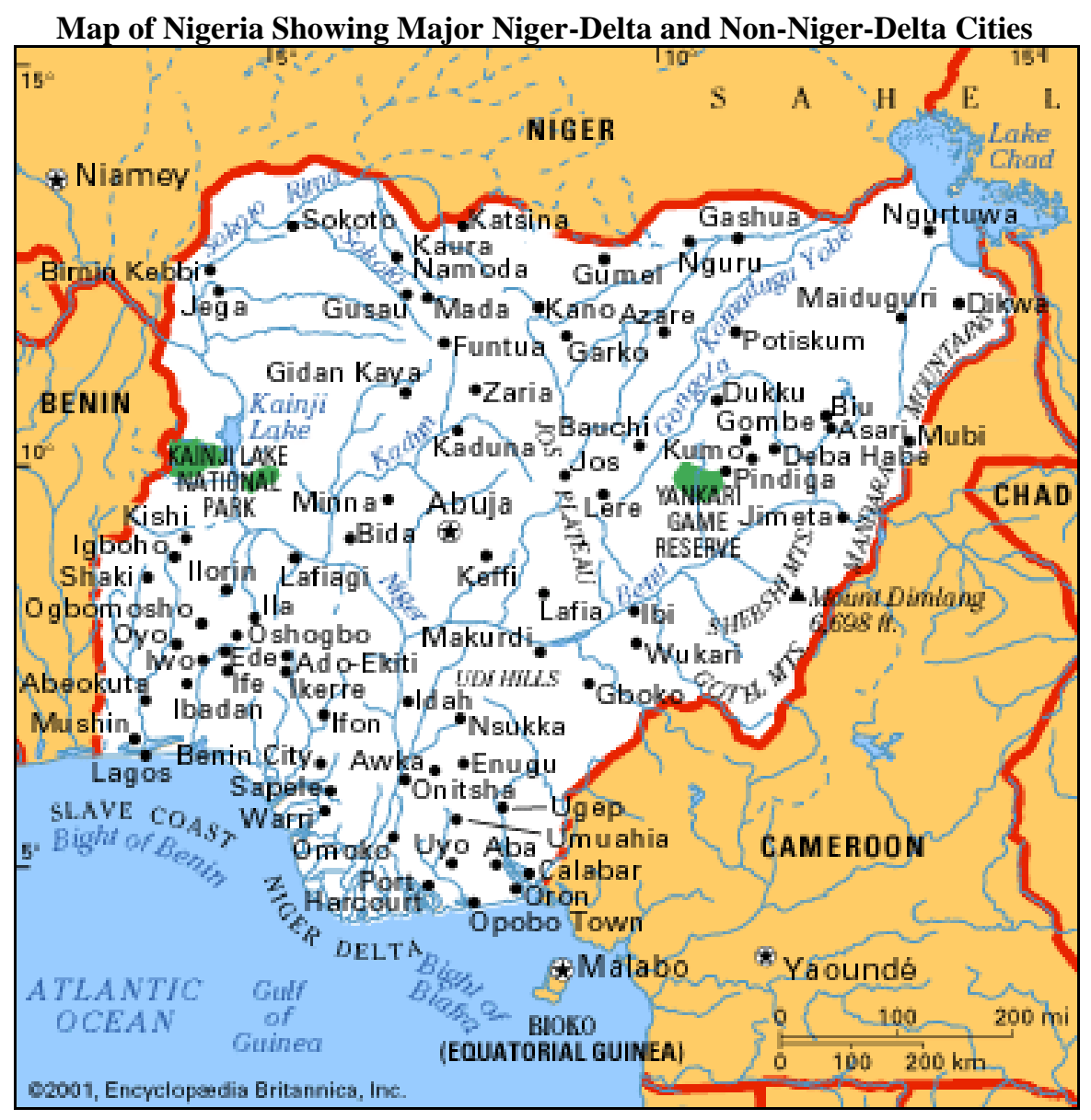

\section{RESULTS AND FINDINGS}

Results showed that participants were unanimous in identifying problems of relationship between the major oil company and their host community as a major factor in the perennial misunderstanding between the company and the people in the area. Even though some of the citizens in the community are employees of the company and some are even contractors of different types, as Reichheld (1993) asserts, in the long term, corporate success will be measured by how well an organization can serve the triad of customers, investors, and employees adequately. Clearly, as major stakeholders, the community can be regarded not only as customers of the major oil company (as they own the land on which the company operates) but also as close neighbors. It is therefore in the company's interest to work at developing the relationship with this very important close neighbor. Results also showed that many people in the community regard the major oil company as the only "government" they see in that general area. Since the company's operation is a joint venture with the federal government of Nigeria, the community finds it much easier to hold the major oil company responsible for providing amenities in the area. This is not uncommon in a developing country with below par leadership and poor infrastructure. As Reichheld (1993) alluded, returns will be maximized by creating and allocating value in such a manner as to minimize churn in the business system because the learning and trust required to sustain value creation cannot exist in an unstable high-churn system. 
Notable scholars of relationship marketing like Berry and Gresham (1986), Beaton and Beaton (1995), and Morgan and Hunt (1994) agree that it is important to foster long-lasting relationships first before addressing the marketing phenomenon. In that vein, it is essential that the management of the oil exploration and production company lay greater emphasis on closer working relationship with the community. Data showed a large degree of feelings of neglect, abandonment, and exploitation by citizens in the oil community. This can be understandable with the high level of unemployment, under-employment, illiteracy, and poor infrastructure common in many oil producing communities in the Niger Delta. As Badmus (2010) argues, the oil-companies have indeed shared their wealth, but insensitive government officials have kept the money and flaunted their new-found wealth in front of the poor. It is the responsibility of the major oil company to redeem this bad image and repair the great damage that has been made.

\section{CONCLUSION AND DISCUSSION}

The literature review analysis has revealed the increasing interest in the marketing field of the aspect of relationship marketing. It is truly the future of the profession. In the case of the perennial problem of this particular major oil company with their host community, necessary steps need to be taken by the company to solidify their relationship with the community. Communication with the community has to increase. Employees should be wooed to provide positive word-of-mouth about the company, to the community, at all times. The company should start viewing the community as one of its clients that should be enjoying long-term relationship with the organization.

The major oil company should do all within its power to start enjoying the trust of the community. This is directly related to peace in the area. In accordance with the findings of Berry and Gresham (2001), the company should endeavor to transform their immediate community from customers to clients. They should start seeing the relationship as moving from courtship to marriage which is a permanent commitment (Beaton \& Beaton, 1995), requiring great efforts from both sides. In this case, the company will have to behave like the husband and take the initiative in many of these corrective actions. This will be in the overall interest of the company and the government, the senior partner in the joint venture relationship with the company.

Related to this is the finding from the research that many of the citizens in the community of the company are appalled at the level of opulence of the typical oil company worker living among them. This situation is worsened by the seeming arrogance of some of the company officials who liaise with the community on behalf of the company. Bowen and Lawler (1992) refer to this category of employees as frontline employees. Such employees actually indirectly portray the company's image by their actions. According to Bowen and Lawler (1992), managers need to make sure that there is a good fit between their organizational needs and their approach to frontline employees. Only well-trained employees with the right type of behavioral characteristics should be given such sensitive roles.

\section{AUTHOR INFORMATION}

Kola Sonaike, Ph.D., Chair of Business and Professor of Management, American InterContinental University, Houston Campus, 9999 Richmond Avenue, Houston, TX 77042, USA. E-mail: ksonaike@ houston.aiuniv.edu

\section{REFERENCES}

1. Badmus, I. A. (2010). Oiling the guns and gunning for oil: Oil violence, arms proliferation and the destruction of Nigeria's Niger-Delta. Journal of Alternative Perspectives in the Social Sciences, 2(4), 323363.

2. Baridam, D.M. (2001). Research methods in administrative sciences. Port Harcourt, Nigeria: University of Port Harcourt Publishing House.

3. Berry, L.L. \& Gresham, L.G. (2001). Relationship retailing: Transforming customers into clients. Business Horizon, Nov. - Dec. 1986.

4. Bowen, D.E. \& Lawler, E.E. (1992). The empowerment of service workers: What, why. How, and when. Sloan Management Review, Spring 1992. 
5. Cooper, D.R. and Schindler, P.S. (2008). Business research methods (10 $0^{\text {th }}$ ed.). New York: McGrawHill/Irwin.

6. Creswell, J.W. (2007). Qualitative inquiry and research design: Choosing among five approaches (2 $2^{\text {nd }}$ ed.). Thousand Oaks: Sage Publications.

7. Dess, G.G., Lumpkin, G.T., \& Eisner, A.B. (2008). Strategic management: Text and cases $\left(4^{\text {th }}\right.$ ed.). New York: McGraw-Hill//rwin.

8. Dohrenwend, B.S., Williams Jr., J.A. and Weiss, C.H. (1969). Interviewer biasing effects: Toward a reconciliation of findings. Public Opinion Quarterly, Spring, pp. 121-129.

9. Folkman, S. and Lazarus, R.S. (1985). If it changes, it must be a process: Study of emotion and coping during three stages of a college examination. Journal of Personality and Social Psychology, 48, 150-170.

10. Grewal, D. \& Levy, M. (2009). Marketing. New York: McGraw-Hill/Irwin.

11. Hill, C.E. (1993). Editorial. Journal of Counseling Psychology, 40, 252-256.

12. Hoshmand, L.L.S. (1989). Alternative research paradigms: A review and teaching proposal. The Counseling Psychologist, 17, 3-79.

13. Iacobucci, D. (2010). MM. OH: South-Western.

14. Kahn, R.L. and Cannell, C.F. (1957). The dynamic of interviewing. New York: Wiley.

15. Kinicki, A. \& Williams, B.K. (2008). Management: A practical introduction (3 ${ }^{\text {rd }}$ ed.). New York: McGrawHill/Irwin.

16. Kotler, P. \& Keller, K.L. (2009). Marketing management $\left(13^{\text {th }}\right.$ ed.). New Jersey: Pearson Prentice Hall.

17. Lamb, C.L., Hair, J.F., \& McDaniel, C. (2010). MKTG3. OH: South-Western.

18. Morgan, R.M. \& Hunt, S.D. (1994). The commitment-trust theory of relationship marketing. Journal of Marketing, July 1994.

19. Payne, A., Christopher, M., Clark, M. \& Peck, H. (1995). Relationship marketing for Competitive advantage. Oxford: Butterworth-Heinemann.

20. Pels, J., Coviello, N.E. \& Brodie, R.J. (2001). Integrating transactional and relational marketing exchange: A pluralistic perspective. Journal of Marketing, Summer 2000.

21. Piantanida, M. and Garman, N.R. (2009). The qualitative dissertation: A guide for students and faculty ( $2^{\text {nd }}$ ed.). Thousand Oaks: Corwin Press Inc.

22. Polkinghorne, D.E. (1993). Two conflicting calls for methodological reforms. The Counseling Psychologist, 19, 13-114.

23. Reichheld, F.F. (1993). Loyalty and the renaissance of marketing. Marketing Management, (10) Vol. 2, No. 4.

24. Schlesinger, L.A. (1983). Job satisfaction, service capability, and customer satisfaction: An examination of linkages and management implications. Boston: Harvard Business School.

25. Schyberger, B.W. (1967). A study of interviewer behavior. Journal of Marketing Research, February, p. 35.

26. Thomas, R.M. (2003). Blending qualitative and quantitative research methods in theses and dissertations. Thousand Oaks: Corwin Press, Inc.

27. Tuodolo, F., \& Ogoriba, T.K. (2002). The kaiama declaration. Retrieved from http//www.ijawcentre.con/kaiama declaration.html 


\section{NOTES}

